\title{
Financial Development-Growth Nexus in Nigeria: Empirical Investigation based on Vector AutoRegressive (VAR) Approach
}

\author{
Innocent Chukwuka Ogbonna ${ }^{1}$ Nkechinyere R. Uwajumogu, $(\mathrm{PhD})^{1}$ \\ Chijioke Godwin ${ }^{2}$ Vitus Sunday Agu ${ }^{3}$
}

1. Department of Economics, Renaissance University, Ugbawka, PMB 01183, Enugu, Enugu State, Nigeria. 2. Department of Banking and Finance, Renaissance University, Ugbawka, Enugu State, Nigeria 3. Department of Economics, Enugu State University of Science \& Technology, Enugu, Nigeria

\begin{abstract}
The paper re-examines the nexus between financial sector development and economic growth in Nigeria over the period 1970-2011. Prior to the study, most of the earlier works use financial deepening to proxy financial development and conclude that financial development do not cause growth. The paper seeks to investigate the hypothesis that financial development is positively related to growth. Using four measures ratios of broad money (MSY), bank deposit liabilities (BDY), domestic credit (DCY), private sector credit (PSY) - to proxy financial development, and adopting Granger causality tests in a VAR framework, the empirical result suggests that financial sector development is positively related to and therefore causes economic growth just as finance is growth dependent - a case of bi-directional causality. The variance decomposition shows that the variations in DCY and PSY are significantly and dominantly affected by MSY. This suggests, among others, that expansion of savings by DMBs through saver-oriented real deposit rate (RDR) translate to domestic credit with higher proportion utilized by the private sector. Among other measures, the establishment of a functional Asset Management Corporation should be hastened to free DMBs from non-performing loans and enhance their ability to expand private sector credits. Equally, to sustain the influence of finance on growth and vice versa, the current reforms in the financial sector should be sustained while focusing on complementary and coordinated institutional and structural reforms in the real sector to ensure simultaneity in the development of the financial and real sectors of the economy.
\end{abstract}

Keywords: Economic Growth, Financial Development, Innovations, Variations, Vector AutoRegressive

\section{Introduction}

Financial development and economic growth nexus has received considerable attention in both theoretical and empirical literature. McKinnon (1973) and Shaw (1973) in their seminal works on financial repression had posited that efficient utilization of resources via highly organized, developed, efficient and liberal financial system enhances economic growth. The authors criticized the Keynesian or financial repressionist view adopted by many governments in developing countries in the early 1970s. They argue that government restrictions on the banking system such as interest rate ceiling, high reserve requirement and directed credit programs hinder financial development and reduce output growth. This thesis, more or less, confirmed the conclusions of earlier works on the importance of the financial system which could be traced back to the works of Bagelot (1873), Hicks (1969) and Schumpeter (1912). Schumpeter (1912) had argued that financial intermediaries through banking system play a pivotal role in fostering technological innovation and economic growth by providing basic services like mobilizing savings, monitoring managers, evaluating investment projects, pooling and managing risks, and facilitating transactions. Further enhancements to this theory were explored in the works of Galbis (1977), Fry (1988), Mathieson (1980), Roubini and Sala-i-Martin (1992) and King and Levine (1993b). However, this school of thought is classified as supply-led theory of financial-growth nexus. Well developed financial markets promote investment and growth by channeling financial resources to the most productive uses.

Despite the fact that some economists have generally emphasized the central role of financial markets in economic growth literature, the empirical evidence on the relationship between financial development and economic growth is apparently inconclusive. Several authors have shown a positive link between financial development and economic growth (King and Levine, 1993b; Christopoulos and Tsionas, 2004; Rousseau and Wachteh, 1998; Khan et al, 2005; Khan and Qayyun, 2006; Kargbo and Adamu, 2010). However, the works of Demetriades and Hussein (1996), Luintel and Khan (1999) show a bi-directional relationship between financial development and economic growth. On the contrary, a Nobel Laureate Robert Lucas (1988) study on financegrowth nexus rejects the existence of any relationship. Recent developments in some economies around the world seem to avail further support for those that reject finance as the cause of growth. Specifically, the rapid growth of many Asian economies including China was achieved despite under-developed financial system (Shan 
et al, 2001). With an average real income growth of 13.5 percent between 2005 and 2007, China's economic performance is extremely difficult to reconcile with the widespread view that its repressive financial system (in the McKinnon-Shaw sense) grossly distorts the optimal allocation of loanable funds and is therefore, inefficient (Odeniran, et al 2010). This puzzle suggests the need for some empirical analysis at country level to examine finance-growth relationship.

Empirically, studies that have used cross-section and panel data generally support the positive effect of financial development on economic growth. On the contrary, studies based on time series data give contradictory results (Kiran et al, 2009; Lee and Wong, 2005). Studies based on cross-sectional data may not satisfactorily address country-specific effects as these countries could be at different stages of financial and economic development, and drawing policy about individual developing countries may be dangerous. According to Badun (2009), differences in financial sector development may reflect different institutional characteristics, different policies, and differences in their implementation. There is the need to conduct time series on individual developing countries to ascertain country-specific effect of finance-growth nexus. Establishing this relationship is crucial because it has significantly different implications for development policy (Calderon and Liu, 2003; Kiran et al, 2009).

However, in spite of the prominent role of the financial sector in influencing economic growth, Nigeria is still characterized by under-developed financial markets which constrain resource mobilization and allocation and hinder economic growth. In realization of this and aware that an efficient financial system is one of the foundations for building sustained economic growth, financial sector reform policies were adopted in the mid 1986 as part of Structural Adjustment Programme (SAP) to ensure a competitive and efficient financial sector that has the capacity to drive the economy from austerity to prosperity. In 2004, the consolidation exercise in the banking industry took a leading role in the National Economic Empowerment and Development Strategy (NEEDS), which was put in place at that time to drive the economic agenda of the government. In 2009, as part of the broad economic measures to respond to the adverse effects of the global financial and economic crises, the Central Bank of Nigeria (CBN) in conjunction with the fiscal authorities spearheaded measures to avert a collapse of the financial system with a view to maintaining economic growth (Odeniran and Udeaja, 2010). All these policy measures have helped the gradual improvement in the mobilization of financial savings and hence the financial development indictors compared with the pre-SAP situation. As table 1.1 shows, trends in financial development indicators reveal a modest improvement of the financial sector. As GDP ratio, bank deposit liabilities, broad money supply (M2), domestic credit, credit to the private sector and investment as ratio of GDP accounted for $21.1 \%, 14.95 \%$, NA $\%, 6.79 \% 14.8 \%$ respectively in 1970 but rose to $53.0 \%, 34.4 \%$, $53.2 \%, 22.1 \%$ and $15.2 \%$ respectively in 1986 after SAP was introduced. In 2010 , the figures were $61.0 \%$, $37.8 \%, 32.0 \%, 34.7 \%$ and $13.6 \%$ respectively. Given the rudimentary nature of the financial sector in Nigeria, it is unlikely that the use of one or more indicators separately will reflect the developmental level of the sector. As the choice of the financial development indicator may influence the ultimate findings of study (Kargbo and Adamu (2010), this study will combine the effects of different measures of financial sector development on economic growth as they tend to complement each other.

Table 1.1: Trends in Real GDP and Financial Development Indicators: 1970-2010

\begin{tabular}{|c|c|c|c|c|c|c|c|}
\hline YEAR & RGDP & BDY & MSY & DCY & PSY & INVY & RDR \\
\hline 1970 & 17.5 & 21.2 & 15.0 & NA & 6.8 & 14.8 & 4.5 \\
\hline 1975 & -2.9 & 29.7 & 14.1 & NA & 6.2 & 25.2 & 3.5 \\
\hline 1980 & 5.5 & 32.9 & 23.9 & 21.6 & 12.6 & 22.2 & 6.3 \\
\hline 1986 & 3.2 & 53.0 & 34.4 & 53.2 & 22.1 & 15.2 & 9.8 \\
\hline 1990 & 8.1 & 31.0 & 19.8 & 21.6 & 12.5 & 14.3 & 22.1 \\
\hline 2000 & 5.4 & 29.9 & 19.2 & 14.6 & 11.6 & 7.0 & 10.7 \\
\hline 2005 & 6.5 & 23.3 & 18.1 & 13.0 & 12.6 & 5.5 & 10.8 \\
\hline 2010 & 7.9 & 61.0 & 37.8 & 32.0 & 34.7 & 13.6 & 5.7 \\
\hline
\end{tabular}

Source: CBN Statistical bulletin, various years, authors' computation Key: N/A = Not available

The knowledge gap this paper intends to fill is the empirical examination of the relationship between four different measures of financial sector development and Nigerian economic growth, hence addressing the country's specific dimension to finance-growth debate. Equally, the effect of various financial measures on each other will be examined. In addition, conscious efforts to address the endogeneity problem and provide the framework for examining the possibility of the impact of economic growth on financial sector development are explored. The Vector Auto Regressive approach and Granger causality test will be applied using annual data from 1970-2011. The rest of the paper is organized as follows: section 2 deals with brief review of related literature while section 3 describes the methodology adopted. Results and discussion are given in section 4 while section 5 concludes the paper. 


\section{Section Two: Review of Related Literature}

The relationship between financial development and economic growth has occupied the attention of many scholars both at theoretical and empirical levels. Recent theoretical literature on financial development and economic growth process document four views on the finance-growth nexus - supply driven, that is, those that suggest the provision of an inexpensive and reliable means of payment; demand leading, that is, volume and allocation effect, in which financial activity increases resources that could be channeled into investment while improving resource allocation; mutual impact of finance and growth, that is, risk management effect where the financial system helps to diversify liquidity risks, thereby enabling the financing of riskier but more productive investment and innovations (Greenwood and Jovanovic, 1990; Bencivenga and Smith, 1991); and informational effect, those that postulate that the role of finance in promoting economic performance is over-stressed, that is, where an ex ante information regarding the availability of investment and capital is made available to ameliorate, but not eliminate the effects of asymmetric information (Levine, 2004).

The Solow (1956) and Hicks (1969) growth model which favour a supply-leading approach posits that an increase in savings rate (capital accumulation) will cause the steady-state levels of capital and per capital and per worker output to rise. This implies that the entire production function will shift upwards and increase the economy's efficiency thereby bringing further increases in the saving rate and hence further rise in per capital stock and per-worker output. Among other likely reasons, the financial sector's role as a monitor of how investment projects are carried out contributes to the raising of the production function. However, the Solow model captures only the short-run and medium-term effects of improvements in the financial development since it does not explain the technological progress or long-run economic growth. The limitation in Solow growth model led to the McKinnon 1973, Shaw 1973 theory of financial repression which posits that efficient utilization of resources through a highly organized, developed and liberalized financial system enhances economic growth. Earlier, Schumpeter (1911) had argued that financial intermediation via banking system played a pivotal role in economic development by affecting the allocation of savings thereby improving productivity, technological progress and rate of economic growth.

In support of the supply-leading argument, Patrick (1966) in Kargbo and Adamu (2010) identified two possible directions of causality between financial development and economic growth. These relationships were labeled as the supply-leading and demand-following. The supply-leading view postulates a positive impact of financial development on economic growth, which means that creation of financial institutions and markets increases the supply of financial services and thus leads to economic growth. Patrick (1966) advocated for a supply-leading strategy that ensures the creation of financial institutions and the supply of their assets, liabilities and related services in advance of demand for them. The supply-leading finance performs two functions: to transfer resources from traditional (non-growth) sectors to modern high-growth sectors, and to promote and stimulate an entrepreneurial response in these modern sectors. He argues that supply leading finance would exert a positive influence on capital by improving the composition of the existing stock of capital, allocate efficiently new investments among alternative uses, and raise the rate of capital formation by providing incentive for increase saving and investment. The supply-leading finance will cause economic development through the transfer of scarce resources from savers to investors according to the highest rates of return on investment.

The McKinnon-Shaw hypothesis supports the supply-leading argument of Patrick. McKinnon (1973) suggests a complementarity relationship between the accumulation of money balances (financial assets) and physical capital accumulation in developing countries. He considers an outside model of money demand. The author argues that due to underdeveloped financial markets in most developing countries, there are limited opportunities for external finance and all firms are confined to self-finance. Given that investment expenditures are lumpier than consumption expenditure; potential investors must first accumulate money balances prior to undertaking relatively expensive and indivisible investment projects. The 'debt-intermediation' view proposed by Shaw (1973) is based on an inside money model. He argues that high interest rates are essential in attracting more saving. With more supply of credit, financial intermediaries promote investment and raise output growth through borrowing and lending. Gurley and Shaw (1967), Jung (1986) and Goldsmith (1969) argument are in tandem with the important role financial intermediation plays in economic growth.

However, in the early 1980s the theoretical underpinnings of the financial liberalization theory were criticized by some economists notably, the neo-structuralists, led by Taylor (1983) who predicted that financial liberalization would slow down economic growth.

The demand-leading advocate postulates a causal relationship from economic growth to financial development. Robbinson (1952) argues that finance does not cause growth, but rather, it responds to demands from the real sector. Accordingly, he concludes "where enterprise leads, finance follows". In support of the demand-led hypothesis, Patrick (1966) asserts that the creation of modern financial institutions, their financial assets and liabilities and related financial services are a response to the demand for their services by investors 
and savers in the real sector. He insists that economic growth creates a demand for developed financial institutions and services.

Patrick (1966) in Kargbo and Adamu (2010) however argues that the causal relationship between financial development and economic growth varies according to the stages of economic development. As finance and economic development proceed, the supply-leading characteristics of financial development diminish gradually and are eventually dominated by demand-following financial development.

Greenwood and Jovanovic (1990) assume a positive two-way causal relationship between financial development and economic growth when they presented a model that allows for the examination of the relation between growth and income distribution, and between financial system and economic development. According to the authors, financial institutions acquire and analyze information about investment opportunities and channel funds to the most productive uses, thereby increasing the return on investment and growth. On the other hand, growth supplies the resources needed to implement and manage a costly financial structure. King and Levine (1993b) agree with Greenwood and Jovanovic view when they assert that financial markets assist in the efficient allocation of resources which increase the probability of successful innovations.

On the contrary, Nobel Laureate Robert Lucas (1988) dismisses finance as the cause of economic growth insisting that finance is an "over-stressed" determinant of growth. A highly liberalized and developed financial market may well turn out to be an impediment to growth when it induces volatility and discourage risk averse investors from investing (Singh, 1977). Easterly, et al (2000) supports this view when they argue that financial crises in emerging market economies around the world over the past 20 years highlights the degree inherent in financial liberalization without adequate domestic restructuring in the context of participation in an increasingly globalized financial system.

\section{II.1 Empirical Review}

A lot of studies testing finance-growth relationship have been carried out using modern econometric tools and cross-country data. Despite enormous heterogeneity across countries, regions, financial factors and direction of causality (Eschenbach, 2004), a number of observation backed by empirical evidence have emerged. Empirically, some findings support supply-leading hypothesis. King and Levine (1993b) in Kargbo and Adamu (2010), used cross-section analysis to examine the relationship between financial development and economic growth during the period 1960-89. The measures of financial development used are the ratio of liquid liabilities of banks and non-bank institutions to GDP, ratio of bank credit to the sum of bank and central bank credit, ratio of private credit to domestic credit and ratio of private credit to GDP. The study found that the level of financial development predicts future economic growth and future productivity advances. The authors have interpreted it as evidence of a causal relationship that runs from financial development to economic growth.

Similarly, Rousseau and Sylla (1999) examine the historical role of finance in the U.S. from 1790-1850 and find a strong support for finance led growth. As a follow-up, they examine the Meiji era of Japan (18681884 ) and shows that the financial sector was instrumental in boosting Japan's explosive growth prior to the First World War. In another study using time series analysis, Rousseau and Wachtel (1998) investigated the nexus between finance and growth in five industrialized nations and conclude that there is a significant positive relationship between financial depth and economic growth.

Neusser and Kugler (1998) using time series analysis examined the finance-growth nexus for 13 Organization for Economic Cooperation and Development (OECD) countries for the period 1970-1991 and found a positive relationship between financial development and economic growth. The authors found that the causal structure underlying the relationship varies widely across countries. Similarly, Odedokun (1996) examined the relationship between financial development and economic growth for 71 developing countries with varying periods from 1960-1980 and concludes that financial intermediation promotes economic growth.

Christopoulos and Tsionas (2004) conducted a study on 10 developing countries using panel data to analyze the relationship between financial development and economic growth. Using the ratio of total bank deposits liabilities to nominal GDP as a measure of financial depth and included the ratio of investment to GDP and inflation rate as control variables, the authors showed the presence of long-run causality running from financial development to economic growth but there was no evidence of bi-directional causality. The short-run result found no evidence of causality between financial deepening and output growth. Finally, the authors suggest that improvement of financial markets will have positive effect on growth.

$\mathrm{Xu}$ (2000), using vector auto regressive approach rejects the hypothesis that finance simply follow growth. Guiso et al, (2002) examined individual regions of Italy and conclude that local financial development enhances the probability that an individual starts a business, increases industrial competition, and promotes the growth of firms.

Khan et al (2005) examined the link between financial development and economic growth in Pakistan over the period 1971-2004 using auto regressive distributed lag approach. Using ratio of total bank deposits liabilities to nominal GDP as a measure of financial depth and included the ratio of investment on GDP as 
control variable, the authors found that financial depth exert positive and significant impact on economic growth in the long-run but insignificant relationship in the short-run. The ratio of investment to GDP also showed positive impact on economic growth in short-run but insignificant in the long-run. The authors finally recommend that policy makers should focus attention on the creation of modern financial institutions in the banking sector and the stock market to promote economic growth.

Apergis et al (2007) using panel data analysis for 15 member-countries of OECD and 50 non-OECD countries investigated the relationship between financial depth and economic growth and found a positive relationship them. Similarly, Kiran et al (2009) employed panel analysis and Fully Modified OLS (FMOLS) methods to examine the relationship between financial development and economic growth for 10 emerging economies over the period 1968-2007. The authors used three measures of financial development (ratio of liquid liabilities to GDP, bank credit to GDP, and private sector credit to GDP) to quantify the impact of financial development on economic growth and concluded that financial development exerts positive and statistically significant impact on growth.

Sanusi and Salleh (2007) analyzed the relationship between financial development and economic growth in Malaysia covering the period 1960-2002 using three measures of financial development. These are ratio of broad money to GDP, credit by the banking sector, and deposit money banks liabilities to GDP. By employing the auto regressive distributed lag approach, the study found that ratio of broad money to GDP, and credits by the banking sector exert positive and statistically significant impact on economic growth in the longrun. The result also indicates that an increase in investment will promote economic growth in the long-run.

Kargbo and Adamu (2010) examined the relationship between financial development and economic growth in Sierra Leone using the period 1970-2008. Employing the method of Principal Component to construct a Financial Sector Development Index (FSDI) which is used to proxy development in the financial sector and using auto-regressive distributed lag (ARDL) approach, found a positive and statistically significant relationship between financial development and economic growth. They further found a unique cointegrating relationship among real GDP, financial development, investment and real deposit rate and concluded that investment is an important channel through which financial development feeds economic growth.

Some empirical evidence are also in support of demand-leading hypothesis that finance responds to the demand of the real sector, meaning that growth has a feedback effect on financial markets. Shan, et al (2001) examined the relationship between financial development and economic growth in China and reports that economic growth causes China's financial development. Demetriades and Hussein (1996) employing the ratio of bank deposit liabilities to GDP, and ratio of bank claims on the private sector to GDP as financial indicators examined the relationship between financial development and economic growth on sixteen countries for the period 1960-1990 using time series analysis, found that the direction of causality between financial development and long-run economic growth runs in different ways for different countries.

Goldsmith (1969) examined data from 35 countries for the period 1860-1963 using ratio of financial intermediary assets to gross national product to measure financial development and found that finance and economic development are positively correlated over periods as long as several decades. This result leaves some puzzle unresolved because each variable has a feedback effect on the other. Explaining the puzzle, Goldsmith (1969) explains that financial development mainly occurs during the early stages of output growth when countries have low levels of income.

Some empirical studies reject the finance-led-growth hypothesis. DeGregorio and Guidotti (1995) in their study of twelve Latin American Countries for the period 1950-1985 found a negative relationship between financial development and growth. Similarly, a study by Boyrau-Debray's (2003) on the relationship between China's financial development and economic growth found that credit given by the banking system at the state level of China has a negative impact on provincial economic growth. Lucas (1988) examination of the relationship between financial development and economic growth rejects the hypothesis that finance is a major determinant of growth, insisting that economists over-stress the role of finance on growth. Mohammed (2008) investigated the relationship between financial development and economic growth in Sudan over the period 1970-2004 using the ratio of M3 to GDP and ratio of credit to the private sector (CPS) to GDP as a financial indicators. Adopting the auto-regressive distributed lag approach, the author found a weak relationship between finance and economic growth. Specifically, the coefficient of M3/GDP was negative and significant while the ratio of CPS to GDP was equally negative but insignificant.

Empirical studies on finance-growth dynamics for Nigeria give conflicting results. Nzotta and Okereke (2009) examined the relationship between financial development and economic growth for Nigeria over the period 1986-2007 using two stages least square technique and found that financial deepening did not support economic growth in Nigeria. On the other hand, Afangideh (2009) in his study using three stage least square framework for the period 1970-2005 found that a developed financial sector alleviates growth financing constraints of investors by increasing bank credit and investment activities thereby promoting growth.

Odeniran and Udeaja (2010) examined the relationship between financial development and economic 
growth in Nigeria over the period 1960-2009 using four indicators to measure financial development - ratios of M2/GDP, growth in net domestic credit to GDP, growth of private sector credit to GDP and growth in banks deposit liability to GDP. Adopting Vector Auto-regressive approach and Granger causality tests, the authors found a bi-directional causality between some of the proxies of financial development and economic growth. Specifically, they found that all measures of financial development except M2/GDP granger cause output even at 1 percent level of significance. Agu and Chukwuma (2008) investigating the finance-growth relationship in Nigeria between 1970-2005 using augmented Granger causality test found evidence to support both demandand supply-leading hypotheses, depending on the financial deepening indicator being used.

Oluitan (2009), using multivariate model in her study on bank credit and economic growth in Nigeria, found a unidirectional causality between the variables, and that real output causes financial development and not vice versa. Her finding also reveals that export of oil and non-oil are not significant in driving financial development and that the financial sector is highly dependent on foreign capital inflows. On the other hand, Sulaiman, et al (2012) adopting Johansen co-integration and error correction model in their study on the effect of financial liberalization on economic growth in developing countries with Nigeria as the country of study conclude that financial liberalization has a growth-stimulating effect on Nigeria. The authors recommend that economic stability should be pursued before implementing any form of financial liberalization measures.

\section{III.1 Model and Data Sources}

\section{Model, Data Sources, Measurement and Estimation Techniques}

The theoretical and empirical literature discussed above highlight the positive relationship between real income, financial development and real interest rate. McKinnon (1973) had argued that the correlation between growth and financial depth is derived from the complementarity between the accumulation of money balances (financial assets) and physical capital in developing countries. Shaw (1973) hypothesizes that financial intermediaries enhance investment which, in turn, raises the productivity level. Kargbo and Adamu (2010) postulate that a positive real interest rate improves financial depth through raising the volume of financial saving mobilization and promotion of growth via increases in the volume of productivity of capital. World Bank (1989) states that high real interest rates exert a positive effect on the average productivity of physical capital by discouraging investors who may wish to invest in low return projects. However, a limitation on financial sector is that there is no single measure of financial sector development (Odeniran and Udeaja (2010), therefore, instead of using a single proxy, four measures are employed in this study in order to improve the robustness of the results.

These studies used different analytical approaches, ranging from cross country growth regression used by King and Levine (1993), panel techniques used by Rioja and Valev (2003) and time series by Khan and Qayyum (2006). However, according to Demetriades and Andrianova (2003), 'it is difficult to draw out any reliable policy implications from cross country or panel regressions, and those conclusions that may be drawn from time series studies for individual countries cannot be generalized.' Based on this, time series is more applicable for single country study and hence time series method of estimation as used by Khan and Qayyum (2006), Kargbo and Adamu (2010), Odeniran and Udeaja (2010), Demetriades and Hussein (1996) will be adopted. This according to Demetriades and Andrianova (2003), allows the use of appropriate statistical procedures, like cointegration to test the long run relationships and Granger causality to determine the direction of causality between variables in a series.

Based on these theoretical views and following Christopoulos and Tsionas (2004), Khan, et al (2005), Kargbo and Adamu (2010), Odeniran and Udeaja (2010), the relationship between economic growth and financial development is specified with some modifications as:

$\mathrm{RY}=\mathrm{f}(\mathrm{MSY}, \mathrm{BDY}, \mathrm{DCY}, \mathrm{PSY}, \mathrm{INVY}, \mathrm{RDR})$

Econometrically, the model becomes:

$$
R Y=b_{0}+b_{1} M S Y+b_{2} B D Y+b_{3} D C Y+b_{4} P S Y+b_{5} I N V Y+b_{6} R D R+\varepsilon \ldots \ldots \ldots
$$

where RY is real GDP, MSY is M2-to-GDP ratio, BDY is bank deposit liabilities ratio to GDP, DCY is domestic credit ratio to GDP, PSY is private sector credit as GDP ratio, INVY is ratio of investment to GDP, RDR stands for real deposit rate, while $\varepsilon$ represents the white noise. The coefficients of MSY, BDY, DCY, PSY, INVY and RDR are all expected to have a positive sign in line with the theoretical literature, hence $b_{1}-b_{6}>0$. The paper employs yearly data for the period 1970 to 2011 sourced from central bank of Nigeria (CBN) statistical bulletin for various years.

\section{III.2 Data Description and Measurement}

As there is no single measure of financial development (Odeniran and Udeaja 2010), choosing appropriate measure of financial development indicators is an extremely difficult task due to the diversity of financial services catered for in the financial system (Ang and McKibbin, 2005). Due to the under-developed financial markets, and because deposit money banks (DMBs) dominate the financial sector and account for 
above $90 \%$ of transactions within the system in Nigeria (Oluitan 2009), the indicators of financial development used in the study only reflect developments in the banking sector. Several indicators of financial development have been used as proxy for depth of financial sector in the empirical literature. However, in this paper, four indicators are used:

The first measure which is ratio of broad money (M2) to GDP (MSY), otherwise known as financial deepening measures the degree of monetization in the economy and the depth of the financial sector. It equally depicts an expansion of payment and saving functions (Odeniran and Udeaja 2010). The second is the ratio of bank deposit liabilities to GDP (BDY) which measures the capacity of banks to perform its core role of mobilizing savings from the surplus to the deficit sectors. BDY is calculated by subtracting currency in circulation from M2 and dividing by nominal GDP. The third measure, the domestic credit as ratio of GDP (DCY) reflects the extent to which financial intermediaries allocate society's savings, the firms' use of credit to support internal funds. The fourth measures the ratio of private sector credit to GDP (PSY), and excludes the public sector credit and therefore reflects the extent to which the banking system channels funds to the private sector and are therefore able to identify profitable investments, facilitate risk management and growth.

Real deposit rate (RDR) is the price paid to savers to postpone consumption to a future date. The higher the RDR the higher the propensity to save and the more funds are mobilized for credit by DMBs. The variable is expected to relate positively with real output growth and is in tandem with the supply leading view of the financial development-income growth prediction given the McKinnon-Shaw postulation. Investment is proxied by the ratio of gross capital formation to nominal GDP and is expected to relative positively with growth of output.

\section{III.3 Estimation Techniques}

To examine the existence of stochastic non-stationary in the series the paper tests for the order of integration of the individual time series thorough the unit root tests using the Augmented Dickey Fuller (ADF) and Phillips-Perron (PP), which are stated in their generic form as follows:

$$
\Delta \mathrm{Y}_{\mathrm{t}}=\beta_{1}+\beta_{2}+\mathrm{s} \mathrm{Y}_{\mathrm{t}-1}+\mathrm{SY}_{\mathrm{t}-1}+\sum_{t-1}^{m} \delta Y t-1+\varepsilon t \ldots \ldots \ldots \ldots \ldots
$$

where $\Delta=$ difference operator, $\mathrm{Y}_{\mathrm{t}}=$ each of the series, $\mathrm{Y}_{\mathrm{t}-1}=$ the lag of each series and $\varepsilon t$ is pure white noise satisfying all the classical assumptions. Equation 3 permits the test to determine if the variable $Y_{t}$ is a stationary series. The null hypothesis in the ADF/PP tests is that $Y_{t}$ is non-stationary, that is, has a unit root $\left(H_{0}: \beta=0\right)$ and is rejected if $\beta$ is significantly negative $\left(\mathrm{H}_{\mathrm{a}}: \beta<0\right)$. If the calculated ADF/PP statistic is higher than McKinnon's critical values, then the null hypothesis $\left(\mathrm{H}_{\mathrm{o}}\right)$ is rejected and the series is stationary or integrated of order zero $\mathrm{I}(0)$. Alternatively, non-rejection of the $\mathrm{H}_{\mathrm{o}}$ implies non-stationarity leading to the conduct of the test on the difference of the series until stationarity is achieved and the $\mathrm{H}_{\mathrm{o}}$ is rejected.

After establishing the unit root properties of the variables, the next step is to test for actual numbers of co-integrating equations that exist among the variables, that is, whether a long run cointegrating relationship exist among the variables in equation 2. Cointegration tests are undertaken based on the Johansen and Juselius (1990) maximum likelihood framework. The purpose is to see whether there exists a long run equilibrium relationship among the variables. Johansen and Juselius cointegration technique actually represents a multivariate generalization of the Dickey Fuller test. It follows the vector autoregressive process, for instance, regressing $\Delta \mathrm{X}_{\mathrm{t}}$ on $\mathrm{X}_{\mathrm{t}-1}$ and $\Delta \mathrm{X}_{\mathrm{t}-1}$ for all $\mathrm{i}=1, \ldots ., \mathrm{k}-1$ thus:

$$
\begin{aligned}
& \Delta X t=\delta X t-1+\sum_{i=1}^{k-1} \gamma i \Delta X t-i+\varepsilon t \ldots \ldots \ldots \\
& \text { With: } \delta=\sum_{i=1}^{k} \boldsymbol{A} i-\mathbf{I} p \text { and } \Gamma i=\sum_{j=i+1}^{k-1} A j .
\end{aligned}
$$

Where $\mathrm{Xt}$ is (nx1) vector of $\mathrm{P}$ variables, $\delta$ is a matrix coefficient of lagged variables, $\mathrm{Ai}$ is (nxn) matrix of parameters, $i$ is (nxn) identity matrix and $\epsilon_{t}$ is $(n x 1)$ vector of innovations. The rank of matrix ' $r$ ' represents the number of co-integrating vectors.

Two test statistics, the trace and the maximum eigenvalue tests were used to test the hypothesized existence of $r$ cointegrating vectors. The trace statistic ( $\lambda$-trace) tests the null hypothesis that the number of distinct cointegrating vectors is less than or equal to $r(n \leq r)$ against a general alternative while the maximum eigenvalue $(\lambda$-max) test statistic tests the null hypothesis that the number of cointegrating vectors is $r(r=1)$ against the alternative of $r>1$ cointegrating vectors.

Next, we specify a Vector AutoRegressive (VAR) model of order P (i.e VAR[P]) to test the null hypothesis that financial sector development does not Granger-cause economic growth. The VAR approach facilitates investigation of dynamic interactions among jointly endogenous variables in stationary multivariate systems without imposing a priori structural restrictions. One advantage of this approach is that it relieves the investigator of the task of deciding which variables are endogenous or exogenous. In addition, the problems associated with simultaneous equation models are avoided because VARs do not include current variables as regressors (Odeniran and Udeaja (2010). A VAR model of the form below is estimated:

$$
\begin{aligned}
& \mathrm{X}_{\mathrm{t}}=\mathrm{C}+\Pi_{\mathrm{i}}, \mathrm{t}-1+\Pi_{1} \mathrm{X}_{\mathrm{i}, \mathrm{t}-2}+\ldots \ldots \ldots \ldots . .+\Pi_{\mathrm{t}-\mathrm{p}}{ }_{1} \mathrm{X}_{\mathrm{i}, \mathrm{t}-\mathrm{p}}+_{1}+\epsilon_{\mathrm{t}} \ldots \ldots \ldots . \\
& \mathrm{t}=1,2 \ldots . \mathrm{p} \quad \mathrm{I}=1,2 \ldots \ldots \mathrm{m}
\end{aligned}
$$


where $\mathrm{c}$ is a constant, $\mathrm{X}_{\mathrm{t}}$ is a $(\mathrm{nx} 1)$ vector of variables being considered in the system.

$\mathrm{X}_{1 \mathrm{t}}$ variable is said to Granger-cause another $\mathrm{X}_{2 \mathrm{t}}$ variable if any of the lagged values of $\mathrm{X}_{1 \mathrm{t}}$ is significant in the equation for $X_{2 t}$. On the other hand, if all the lagged values of $X_{1 t}$ are jointly insignificant in $X_{2 t}$ equation, the null hypothesis is accepted, that is $X_{1 t}$ variable does not Granger-cause $X_{2 t}$.

A modified version of Lee and Wong (2005) in Odeniran and Udeaja (2010) is presented where the equations in the VAR model contain the real per capita output and various measures of financial development indicators. The Schwarz criterion is used to determine the number of lags to be included. Following specification of VAR equation is presented:

$$
\begin{aligned}
& \Delta \mathrm{RY}=\beta_{1}+\alpha_{11} \Delta \mathrm{RY}_{\mathrm{t}-1}+\alpha_{12} \Delta \mathrm{RY}_{\mathrm{t}-2}+\partial_{13} \mathrm{FI}_{\mathrm{t}-1}+\Delta_{14} \Delta \mathrm{FI}_{\mathrm{t}-2} \ldots \ldots \ldots \ldots \\
& \Delta \mathrm{FI}=\beta_{2}+\alpha_{21} \Delta \mathrm{RY}_{\mathrm{t}-1}+\alpha_{22} \Delta \mathrm{RY}_{\mathrm{t}-2}+\partial_{23} \Delta \mathrm{FI}_{\mathrm{t}-1}+\Delta_{24} \Delta \mathrm{FI}_{\mathrm{t}-2} \ldots \ldots \ldots . .
\end{aligned}
$$

If it is only the lagged values of the financial sector variables in equation 7 that are significant, it is indicative that financial sector development Granger-causes economic growth. However, if it is only the lagged value of the growth variable in equation 8 that is significant, we can infer that economic growth Granger-causes financial development. Equivalently, if the lagged independent variables in the two equations are significant, we conclude that a bi-directional causality exists between financial sector development and economic growth.

\section{Results And Discussions}

From the results in table 4.1, only real per capita output (RY) and ECM are stationary at levels while financial deepening (MSY), bank deposit liability (BDY), domestic credit (DCY), private sector credit (PSY), investment (INVY), and real deposit rate (RDR) are not. The variables however became stationary at first difference suggesting a I(I) series.

Table 4.1: ADF and PP Unit Root Test Results

\begin{tabular}{|lcccccccc|}
\hline Variable & \multicolumn{2}{c}{ Level I(0) } & \multicolumn{2}{c|}{$\mathbf{1}^{\text {st }}$ Difference I(I) } & Variables & Level I(0) & \multicolumn{2}{c|}{$\mathbf{1}^{\text {st }}$ Difference I(I) } \\
s & ADF & PP & ADF & PP & ADF & PP & ADF & $-3.993^{* *}$ \\
RY & $-5.316^{*}$ & $5.338^{*}$ & - & - & DCY & - & - & $-3.876^{*}$ \\
MSY & - & - & $-6.019^{*}$ & $-6.041^{*}$ & PSY & - & - & $-4.722^{*}$ \\
BDY & - & - & $-5.232^{*}$ & $-5.201^{*}$ & INVY & - & - & $-5.595^{*}$ \\
ECM & $-8.325^{*}$ & $-8.306^{*}$ & - & - & RDR & - & - & $-7.658^{*}$ \\
\hline
\end{tabular}

Notes: (1) ADF and PP = Unit root tests with constant and trend

(2) *and ** indicate statistical significance at the $1 \%$ and $5 \%$ levels respectively

(3) McKinnon (1973) critical values are: $-4.233(1 \%)$ and $-3.536(5 \%)$ respectively for level form; $-4.242(1 \%)$ and $-3.540(5 \%)$ respectively for 1 st difference; and $-4.325(1 \%)$ and $-3.576(5 \%)$ respectively for level form of ECM.

Having established the unit root properties of the variables, we then tested for the actual number of cointegrating equations that exist among the variables, that is, whether a long run co-integrating relationship exist among the variables in our model 2. The results as presented in table 4.2 reject the null hypothesis $\left(\mathrm{H}_{0}\right)$ at $95 \%$ confidence level for both trace ( $\lambda$-trace) and maximum eigen-value $(\lambda$-max) statistics. For each of the statistic, table 4.2 indicates four co-integrating vectors in the model. Thus, MSY, BDY, DCY, PSY, INVY and RDR cointegrate (have long run) with RY and is consistent with the finance-led theories.

Table 4.2: Results from Johansen Co-integration Rank Test (Trace) and (Maximum Eigen-value)

\begin{tabular}{|c|c|c|c|c|c|}
\hline $\begin{array}{c}\text { Null } \\
\text { Hypothesis }\end{array}$ & Trace Statistic & $\begin{array}{c}\text { Critical Value at 5 } \\
\text { per cent }\end{array}$ & Null Hypothesis & $\begin{array}{c}\text { Maximum-Eigen } \\
\text { Statistic }\end{array}$ & $\begin{array}{c}\text { Critical value at 5 } \\
\text { percent }\end{array}$ \\
\hline $\mathrm{r}=0^{*}$ & 177.1837 & 124.24 & $\mathrm{r}=0^{*}$ & 210.6839 & 146.76 \\
\hline $\mathrm{r}=\leq 1^{*}$ & 128.2089 & 94.15 & $\mathrm{r}=1^{*}$ & 157.2981 & 114.90 \\
\hline $\mathrm{r}=\leq 2^{*}$ & 82.0013 & 68.52 & $\mathrm{r}=2^{*}$ & 109.4965 & 87.31 \\
\hline $\mathrm{r}=\leq 3^{*}$ & 50.6345 & 47.21 & $\mathrm{r}=3^{*}$ & 68.91055 & 62.99 \\
\hline $\mathrm{r}=\leq 4$ & 22.5989 & 29.68 & $\mathrm{r}=4$ & 39.91540 & 42.44 \\
\hline $\mathrm{r}=\leq 5$ & 5.7675 & 15.41 & $\mathrm{r}=5$ & 16.83149 & 25.32 \\
\hline $\mathrm{r}=\leq 6$ & 0.9018 & 3.76 & $\mathrm{r}=6$ & 4.838632 & 12.25 \\
\hline
\end{tabular}

Note: $r=$ number of co-integrating vectors. Trace and Maximum Eigenvalue tests indicate 4 co- integrating equations at the $5 \%$ level while * denotes rejection of the null hypothesis at the $5 \%$ level.

Table 4.3 presents the correlation matrix. As expected, there is positive correlation between RY and all financial development indicators. Equivalently, there is also positive correlation among the various measures of financial development with the highest level of correlation between MSY variable and BDY, followed closely by that between MSY and DCY. The correlation matrix is therefore in conformity with a priori expectations.

Table 4.3: Correlation Matrix 
Financial Development-Growth Nexus in Nigeria: Empirical Investigation based on Vector

\begin{tabular}{lcccccc}
\hline $\begin{array}{l}\text { Correlation } \\
\text { Probability }\end{array}$ & RY & MSY & BDY & DCY & PSY & INVY \\
RY & 1.000000 & & & & & \\
MSY & 0.966502 & 1.000000 & & & & \\
BDY & 0.956789 & 0.920619 & 1.000000 & & & \\
DCY & 0.901880 & 0.883067 & 0.754792 & 1.000000 & & \\
PSY & 0.314412 & 0.327775 & 0.323944 & -0.390898 & 1.000000 & 1.000000 \\
INVY & 0.787884 & 0.732595 & 0.693241 & 0.712020 & 0.183868 & 0.197128 \\
RDR & 0.234367 & -0.337796 & 0.289753 & 0.020359 & 0.292960 & 1.000000 \\
\hline
\end{tabular}

Table 4.4: Pairwise Granger Causality Tests

\begin{tabular}{|l|l|l|l|l|}
\hline Null Hypothesis: & Obs & F-Statistic & Prob. \\
\cline { 2 - 5 } & MSY does not Granger Cause RY & 40 & 0.28803 & 0.75150 \\
RY does not Granger Cause MSY & & 0.37768 & 0.68821 \\
\hline BDY does not Granger Cause RY & 40 & 6.35801 & 0.00706 \\
RY does not Granger Cause BDY & & 5.75301 & 0.01058 \\
\hline & DCY does not Granger Cause RY & 40 & 6.16702 & 0.00356 \\
RY does not Granger Cause DCY & & 6.00427 & 0.05674 \\
\hline & PSY does not Granger Cause RY & 40 & 7.04997 & 0.00897 \\
RY does not Granger Cause PSY & & 0.29833 & 0.73289 \\
\cline { 2 - 5 } & INVY does not Granger Cause RY & 40 & 8.61021 & 0.00103 \\
RY does not Granger Cause INVY & & 5.03876 & 0.06326 \\
\cline { 2 - 6 } & RDR does not Granger Cause RY & 7.11432 & 0.02009 \\
RY does not Granger Cause RDR & & 4.79011 & 0.09832 \\
\hline
\end{tabular}

IV.1 Var

\section{Results And Discussion}

Table 4.4 presents some selected variables from our VAR estimates. The results show that BDY, PSY, DCY, RDR and INVY are significant at 5\% indicative that all the financial indicators employed in our model except MSY granger cause output. We therefore reject the null hypothesis that these variables does not granger cause output and accept instead the alternative hypothesis. The result on MSY in particular is consistent with the findings of Nzotta and Okereke (2009), Odeniran and Udeaja (2010) for Nigeria, but inconsistent with the findings of Oluitan (2009) also for Nigeria. Odeniran and Udeaja (2010) result show that PSY, BDY, DCY were significant even at $1 \%$ in determining output growth in Nigeria.

In addition, and consistent with the findings of Odeniran and Udeaja (2010), Kargbo and Adamu (2010), but inconsistent with Sanusi and Salleh (2007), Khan et al (2005), per capita output also granger causes BDY, DCY, RDR and INVY variables at 5\% level of significance. Hence, the result is in tandem with bidirectional empirical and theoretical postulations.

\section{IV.2 Impulse Response Function}

Impulse response functions are dynamic simulations showing the response of an endogenous variable overtime to a given shock. Table 4.5 presents impulse response functions which trace the asymmetric impact and long run responses of the system variables to one standard deviation shocks to the system innovations spanning over the ten years horizon. The results reveal that per capita output (RY) responds to shocks on bank deposit liability (BDY) and domestic credit (DCY). Specifically, a one standard deviation shock to the innovations in BDY will result to a significant positive response of $97 \%, 146 \%$ and $80 \%$ in second, third and fourth years in RY respectively. Equivalently, a one standard deviation shock in DCY would contribute $31 \%$, $115 \%, 163 \%$ and $96 \%$ to RY in second, third, fourth and fifth years respectively. However, while the increases in RY would be sustained up to the seventh year for one standard deviation shock in DCY and up to the tenth year in RDR, it would last only up to the fourth year given a shock in BDY. The innovations to MSY and PSY do not yield significant RY response as some coefficients even displayed negative signs. 
Table 4.5: Response of RY variable over ten years horizon to given shocks in itself, MSY, BDY, DCY, PSY, INVY and RDR

\begin{tabular}{cccccccc} 
Period & RY & MSY & BDY & DCY & PSY & INVY & RDR \\
\hline \hline 1 & 2.183153 & 0.262363 & 0.527762 & 0.743502 & 0.027700 & 0.568275 & 0.218796 \\
& $(0.28184)$ & $(0.44358)$ & $(0.98676)$ & $(0.86401)$ & $(0.37032)$ & $(0.37395)$ & $(0.37233)$ \\
2 & 0.263140 & 0.149682 & 0.971089 & 0.310159 & 0.162393 & 0.502070 & 1.042895 \\
& $(0.34627)$ & $(0.50751)$ & $(1.38955)$ & $(1.04968)$ & $(0.47548)$ & $(0.41886)$ & $(0.44603)$ \\
\multirow{2}{*}{3} & 0.112449 & 0.575762 & 1.456077 & 1.153532 & 0.648035 & 0.279361 & 1.311914 \\
& $(0.32668)$ & $(0.65587)$ & $(1.61152)$ & $(1.18932)$ & $(0.71840)$ & $(0.41641)$ & $(0.53621)$ \\
\multirow{2}{*}{4} & 0.146729 & 0.681387 & 0.803953 & 1.634918 & 0.493266 & 0.280236 & 0.620092 \\
& $(0.29774)$ & $(0.74024)$ & $(1.53699)$ & $(1.22876)$ & $(0.83121)$ & $(0.37995)$ & $(0.48622)$ \\
5 & 0.061630 & 0.104534 & -0.164545 & 0.959566 & 0.083882 & 0.236946 & 0.568922 \\
& $(0.27532)$ & $(0.74039)$ & $(1.37106)$ & $(1.10702)$ & $(0.80831)$ & $(0.36004)$ & $(0.43694)$ \\
6 & 0.113428 & -0.168028 & -0.544573 & 0.418231 & -0.243590 & 0.140568 & 0.268943 \\
& $(0.27052)$ & $(0.72450)$ & $(1.26559)$ & $(0.97099)$ & $(0.74815)$ & $(0.32256)$ & $(0.39258)$ \\
7 & -0.126770 & -0.443281 & -0.685629 & 0.049548 & -0.541966 & 0.015324 & 0.185014 \\
& $(0.26680)$ & $(0.72024$ & $(1.17645)$ & $(0.87329)$ & $(0.71227)$ & $(0.27395)$ & $(0.36063)$ \\
8 & -0.103141 & -0.480267 & -0.564912 & -0.092216 & -0.535603 & -0.057962 & 0.220794 \\
& $(0.25793)$ & $(0.71125)$ & $(1.04008)$ & $(0.76845)$ & $(0.66716)$ & $(0.22902)$ & $(0.32531)$ \\
9 & -0.130933 & -0.428820 & -0.450165 & 0.006896 & -0.397618 & -0.039526 & 0.202578 \\
& $(0.24712)$ & $(0.68873)$ & $(0.91775)$ & $(0.70255)$ & $(0.60058)$ & $(0.19179)$ & $(0.29014)$ \\
10 & -0.180492 & -0.421145 & -0.425088 & 0.026922 & -0.279728 & -0.007571 & 0.171134 \\
& $(0.23488)$ & $(0.65831)$ & $(0.87715)$ & $(0.73512)$ & $(0.54668)$ & $(0.17304)$ \\
\hline$=$
\end{tabular}

\section{IV.3 Variance Decomposition}

What is the contribution of the different structural shocks on real output (RY)? Variance decomposition of the variables are presented in appendix 1 based on our model over a 10-year horizon. The variance decomposition shows the proportion of the forecast error variance for each variable that is attributable to its own innovations and the innovations in the other variables in our system. It apportions the total fluctuations in a particular variable to the component innovations in the system. Our first major finding is that in general, all the variables except DCY and PSY are largely driven by "own shocks". For instance, variations within the first three years of the forecast horizon in RY, MSY and RDR account for about 100\%, 77\% and 68\%; $98 \%, 72 \%$ and $52 \%$; and, $84 \%, 50 \%$ and $41 \%$ respectively to own variance decomposition. The contribution of BDY to the variations in RY becomes significant as from the fourth year when it rises to $7.4 \%$. About $16.2 \%$ of the variations in RY in the tenth year are explained by BDY. Equivalently, $12.9 \%, 7.7 \%, 5.7 \%$ and $5.4 \%$ are the contributions of RDR, DCY, PSY and MSY respectively to the variations in RY in the tenth year. This means that after BDY, RDR is the next most important variable that explains variations in RY if own shock is assumed away. Thus, the principal drivers of RY are itself, BDY and RDR in that order.

The variations in MSY are driven primarily by itself (99\%), (72\%), and (52\%) in first, second and third years respectively. From the fourth year, all the other variables jointly contribute about $62 \%$ while their contributions rise to $81 \%$ in the tenth year with BDY's $31 \%$ as the principal driver. RY's $3 \%$ contribution to the variations in MSY is indicative that variances in RY have an insignificant contribution to the innovations in MSY.

Regarding the variations in BDY, its own shock constitute about $47 \%$ in first year, $62 \%$ in second year, $58 \%$ and $49 \%$ in the fourth and tenth year respectively. On its part, RY innovations contribute about $52 \%$ in the first year, $31 \%$ in the second year, $22 \%$ and $18 \%$ in the fourth and tenth year respectively. The contributions of DCY to the variations in BDY are about $11 \%$ and $14 \%$ in the fourth and tenth year respectively. Thus, excluding own shock, RY and DCY, all the other variables (RDR, INVY, PSY, MSY) contribute about 19\% of the variations in BDY.

As earlier explained, DCY's and PSY's own shocks do not constitute the dominant contributor to their innovations. With own shock contributions of 37\%, 20\% and 16\% for DCY and 29\%, 18\%, and 5\% for PSY in the first, second and fourth years respectively, MSY's contributions of 59\%, $62 \%$ and $40 \%$ for DCY and $62 \%$, $37 \%$, and $18 \%$ for PSY in same period assume a significant and dominant contributor to the variations in DCY and PSY. This suggests, among others, that expansion of savings by DMBs through saver-oriented RDR translate to domestic credit with higher proportion utilized by the private sector. This finding is consistent with McKinnon (1973) postulation that increase in interest rates will lead to an increase in the volume of financial savings through financial intermediaries and thereby raises investible funds, a phenomenon he calls "conduit effect". Among other measures, the establishment of a functional Asset Management Corporation should be hastened to free DMBs from non-performing loans and enhance their ability to expand private sector credits. The third significant contributor to DCY shocks is from BDY. With $2 \%$ contribution to the variations in DCY in first year, it rose to $16 \%$ in second year, further to $21 \%$ in fourth year and still further to $24 \%$ in the tenth year. The contributions of RY which was insignificant in the first three years became significant in the fourth year with $7 \%, 8 \%$ in eighth year and remained at approximately $8 \%$ in the tenth year indicative that in the long run 
RY is positively associated with DCY.

With $20 \%$ in the third year and $19 \%$ in the tenth year, RY is the single most important variable that predominantly explains the variations in RDR if own innovations is assumed away. With its $11 \%$ in the second year and $16 \%$ in the tenth year, PSY is the next single variable that explains the variations in RDR. This result is suggestive that a reasonable proportion of deposit money banks' (DMBs) deposits attracted due largely to saver-oriented interest rate policies, translate to PSY.

In summary, the variance decomposition shows that the significant variation for each variable is largely due to own shocks, but the case of DCY and PSY give contrary results. Variations in DCY and PSY are largely driven by MSY and BDY rather than by their own shocks. The result of variance decomposition analysis confirms the significant influence of BDY, RDR and DCY on RY and on each other and is indicative of the complementarities and simultaneity between financial sector development indicators and real output. The finding is consistent with our Granger analysis and the long run responses found in the impulse response functions. Thus the policy prescriptions for sustained positive impact of the financial sector on economic growth in Nigeria will be the sustenance of present reforms in the financial sector as well as an expansion of its size, depth, and efficiency that will guarantee a substantial and sustained private sector expansion. Equivalently, the paper recommends that for sustained positive impact of economic growth on financial sector, the development and expansion of financial institutions should not be emphasized unilaterally; rather, the National Economic Planning Commission should focus on complementary and coordinated development strategy aimed at institutional and structural reforms in other areas so as to ensure simultaneous development in the financial and real sectors of the Nigerian economy.

\section{Conclusion}

The paper re-examines the nexus between financial sector development and economic growth in Nigeria. It reviews related literature and conducts empirical analysis employing VAR and Granger Causality techniques to examine the link between financial development and economic growth. Using various measures of financial development as proxy, the study investigates the hypothesis that financial sector development is positively related to economic growth in Nigeria. The study finds that financial sector development is positively related to and therefore causes economic growth just as finance is growth dependent. The bi-directional causality between finance and growth underscores the imperative of a simultaneous development strategy in both the financial and real sectors of the Nigerian economy. Thus, to sustain the influence of finance on growth in Nigeria requires the sustenance of present reforms in the financial sector as well as an expansion of its size, depth, and efficiency for a substantial and sustained private sector expansion. On the other hand, and to avoid one-sided development strategy, the National Economic Planning Commission should focus on complementary and coordinated institutional and structural reforms in the real sector to ensure simultaneity in the development of the financial and real sectors of the economy.

\section{References}

[1]. Afangideh, U.J. (2009) "Financial Development and Agricultural Investment in Nigeria: Historical Simulation Approach" West African Journal of Economic and Monetary Integration Vol. 9, June

[2]. Agu, C.C. and J.O. Chukwu (2008) "Toda and Yamamoto Causality tests between 'bank based' financial deepening and Economic Growth in Nigeria", European Journal of Social Science, 7(2), 189-98

[3]. Ang, J.B. and McKibbin, W.J. (2005) "Financial liberalization, financial sector development and growth: Evidence from Malaysia", Centre for Applied Macroeconomic Analysis (CAMA) Working Paper 5, Australian National University

[4]. Apergis, N., L. Fillipidis and C. Economidou (2007) "Financial deepening and economic growth linkages: A panel data analysis", Review of World Economics, 143, 179-198

[5]. Badun, M. (2009) "Financial intermediation by banks and economic growth: A review of empirical evidence", Financial Theory and Practice, 33(2), 121-152

[6]. Bagehot, W. (1873). A Description of the Money Market, Homewood, IL: Richard D. Irwin, (1992 Edition) Lombard Street.

[7]. Bencivenga, V. R. and Smith, B. D. (1991). Financial Intermediation and Endogenous Growth. Review of Economics Studies, 58(2): 403-44

[8]. Boyreau-Debray, G. (2003) "Financial Intermediation and Growth - Chinese Style" Policy Research Working Paper 3027, The World Bank

[9]. Calderon, C. And Liu, L. (2003) "The direction of Causality between Financial Development and Economic Growth" Journal of Development Economics

[10]. Christopoulos, D.K. and Tsionas, E.G. (2004) "Financial development and economic growth: Evidencee from panel unit root and cointegration tests, Journal of Development Economics, 73, 55-74

[11]. Davis, E.P. and Madsen, J.B. (2008) "Productivity and equity market fundamentals: 80 Years of Evidence for 11 OECD Countries" Journal of International Money and Finance, 1-23

[12]. De Gregorio, J. and P.E. Guidotti. 1995. "Financial development and economic growth". World Development, $23(3)$ : $433-48$.

[13]. Demetriades O.P. and Andrianova, S. (2004) "Finance and Growth: What We Know and What We Need to Know" University of Leicester

[14]. Demetriades, P. O. and Hussein, K.A. (1996). Does Financial Development Cause Economic Growth? Time-

[15]. series Evidence from 16 Countries. Journal of Development Economics, 51, 387-411.

[16]. Easterly, W., R. Islam and J. Stiglitz (2000) "Shaken and Stirred, Explaining Growth Volatility" Annual Bank Conference on Development Economics, World Bank, Washington D.C., USA 
[17]. Eschenbach, F. (2004) "Finance and Growth: A Survey of the theoretical and empirical literature" Tinbergen Institute Discussion Paper, 039/2

[18]. Fry, M.J. 1988. Money, Interest and Banking in Economic Development. Baltimore: Johns Hopkins University Press.

[19]. Galbis, V. (1997) "Financial Intermediation and Economic Growth in Less-Developed Countries: A theoretical Approach. Journal of Development Studies January; 58-72

[20]. Goldsmith, R. W. (1969). Financial Structure and Development. New Haven: Yale University Press.

[21]. Greenwood, J. and B. Jovanovic. 1990. "Financial development, growth and the distribution of income". Journal of Political Economy, 98(5): 1076-1107.

[22]. Guiso, Luigi, Paola Sapienza and Luig Zingales (2002) "Does Local Financial Development Matter? NBER Working Paper W 89223, National Bureau of Economic Research, May

[23]. Gurley, J.G. and E.S. Shaw (1967). "Financial structure and economic development". Economic Development and Cultural Change, 15(31): 257-268.

[24]. Hicks, John (1969) A Theory of Economic History. Oxford; Clarendon Press

[25]. Johansen, S. And Juselius, K. (1990) 'Maximum likelihood estimation and inference on cointegration with applications to the demand for money' Oxford Bulletin of Economics and statistics, 52, 169-210

[26]. Jung, W.S. (1986). Financial Development and Economic Growth. Economic Development and Cultural Change, $34: 336-346$.

[27]. Kargbo, Santigie M. and Adamu, Patricia A. (2009) "Financial development and economic growth in Sierra

[28]. Leone", Journal of Monetary and Economic Integration, Vol. 9, No. 2. [Online], Available: www.wamiimao.org

[29]. Kerian, B., Yavus, N.C., and Guris, B. (2009) "Financial development and economic growth: A panel data analysis of emerging countries", International Research journal of Finance and Economics, 30, 1450-2887

[30]. Khan, M.A. and Qayyum, A. (2006) "Trade liberalization, financial sector reforms, and growth", The Pakistan Development Review, 45 4(2), 711-731

[31]. King, R. and R. Levine (1993b). Finance, Entrepreneurship and Growth: Theory and Evidence. Journal of Monetary Economics, 32, 513-542.

[32]. Lee, C.C. and S.Y. Wong (2005) "Inflationary Threshold Effects in the Relationship between Financial Development and Economic Growth: Evidence from Taiwan and Japan" Journal of Economic Development, 30:1, 306-12

[33]. Levine, R. (2004). More on Finance and Growth: More Finance, More Growth?, Review. Federal Reserve Bank of St. Louis, 85(4), 31-46.

[34]. Lucas, R.E. (1988) "On the mechanics of economic development”, Journal of Monetary Economics, 22(1), 3-42

[35]. Luintel, K.B. and Khan, M.A, (1999) “A quantitative reassessment of the finance growth nexus: evidence from a multicariate VAR", Journal of Development Economics, 60(2), 381-405

[36]. Mathieson, R.J. (1980) "Financial Reform and Stabilization Policy in a Developing Economy. Journal of Development Economics, September: 259-395

[37]. McKinnon, R.I. 1973. Money and Capital in Economic Development. Washington, D.C.: The Brookings Institute.

[38]. Mohammed, S.E. (2008) "Financial-growth nexus in Sudan: empirical assessment based on an autoregressive distributed lag (ARDL) model", Arab Planning Institute Working Paper Series 0803, (online, available): http://www.arab-api.org/wps/wps0803.html

[39]. Neusser, K. And Kugler, M., (1988) "Manufacturing growth and financial development: evidence from OECD countries", Review of Economics and Statistics, 80, 638-646

[40]. Nzotta, S.M. and E.J. Okereke (2009) "Financial Deepening and Economic Development of Nigeria: An Empirical Investigation" African Journal of Accounting, Economics, Finance and Banking Research Vol. 5

[41]. Odedokun, M. O. (1996). Alternative Econometric approaches for Analyzing the Role of thee Financial Sector in Economic Growth: Time-Series Evidence from LDCs. Journal of Development Economics, 50(1), 119-146.

[42]. Odeniran, S.O and Udeaja, E.A(2010) "Financial Sector Development and Economic Growth: Empirical Evidence from Nigeria" Central Bank of Nigeria Economic and Financial Review 48(3) 91-124

[43]. Oluitan, R. (2009) "Bank Credit and Economic Growth: The Nigerian experience" Retrieved on10th August 2013 from http://www.csae.ox.ac.uk/conference/2009-EDRA/papers/094

[44]. Patrick, H.T. (1966) "Financial development and economic growth in under-developed countries", Economic Development and Cultural Change, 14(1), 174-189

[45]. Rioja F. And Valev, N. (2003) "Does One Size Fit All?: A Re-examination of the Finance and Growth Relationship" Social Science Research Network

[46]. Robbinson, J. (1952) The Rate of Interest and other Essays, London: Macmillan

[47]. Roubini, N. and Sala-i-Martin, X. (1992). Financial Repression and Economic Growth. Journal of Development Economics, 39:5-30.

[48]. Rousseau, P.L. and R. Sylla(1999) "Emerging Financial Markets and Early U.S Growth", NBER Working Papers 7448

[49]. Rousseau, Peter L. and Wachtel P. (1998) "Financial intermediation and economic performance: Historical evidence from five industrialized countries" Journal of Money, Credit and Banking, 30, 657-78

[50]. Sanusi, N.A. and N.H.M. Salleh (2007) "Financial development and economic growth in Malaysia: An application of ARDL approach", (online, available: http://www.ibacnet.org/bai2007/proceedings/Papers/2007bai7443.doc

[51]. Schumpeter, J. A. (1912). Theorie der WIrtschaftlichen Entwicklung. Leipzig: Dunker \& Humblot, The Theory of Economic Development: An Inquiry into Profits, Capital, Interest and the Business Cycle, translated by Redvers Opie. Cambridge, MA: Harvard University Press, 1934.

[52]. Shan, J.Z., F. Sun and A. Morris (2001) "Financial Development and Economic Growth, Review of International Economics 9, 44354

[53]. Shaw, E.S. 1973. Financial Deepening in Economic Development. New York: Oxford University Press.

[54]. Singh, A. (1997) "Financial liberalization, stock markets and economic development", Economic Journal, 107, 771-782

[55]. Solow, Robert (1956) "A Contribution to the Theory of Economic Growth" Quarterly Journal of Economics, 70(1), 65-94

[56]. Sulaiman, L.A, M.O. Oke, B.A. Azeez (2012) "Effect of Financial Liberalization on Economic Growth in Developing Countries: The Nigerian Experience" International Journal of Economics and Management Sciences Vol. 1, No. 12, 16-28

[57]. Taylor J. And J. Williams (2008) 'A Black Swan in the Money Market'

[58]. Wachtel. P. (2003). How Much Do We Really Know About Growth and Finance?, Federal Reserve Bank of Atlanta Economic Review, 88, 34-47.

[59]. World Bank (1989) World Development Report, New York: Oxford University Press.

[60]. Xu, Z. (2000) "Financial Development, Investment and Growth" Economic Inquiry 38:331-344 
Appendix 1: Variance Decomposition (per cent of total variance)

Appendix 1a: Variance Decomposition of RY:

\begin{tabular}{|c|c|c|c|c|c|c|c|c|}
\hline Period & S.E. & RY & MSY & BDY & DCY & PSY & INVY & RDR \\
\hline 1 & 2.183153 & 100.0000 & 0.000000 & 0.000000 & 0.000000 & 0.000000 & 0.000000 & 0.000000 \\
\hline 2 & 2.512708 & 76.58579 & 7.849909 & 0.099566 & 1.798895 & 0.400611 & 2.394849 & 10.87039 \\
\hline 3 & 2.675356 & 67.73350 & 8.638755 & 1.599648 & 3.051351 & 0.377522 & 8.811920 & 9.787306 \\
\hline 4 & 2.836396 & 60.52814 & 7.691501 & 7.403510 & 3.297447 & 2.975544 & 9.392619 & 8.711242 \\
\hline 5 & 2.964290 & 55.46108 & 7.042456 & 8.601427 & 4.794049 & 4.747243 & 9.032028 & 10.32172 \\
\hline 6 & 3.108988 & 50.55180 & 6.569604 & 11.95842 & 6.119056 & 4.911358 & 8.583829 & 11.30593 \\
\hline 7 & 3.252242 & 46.34842 & 6.099368 & 15.20370 & 7.067562 & 4.748700 & 9.080685 & 11.45156 \\
\hline 8 & 3.369092 & 43.28291 & 5.806107 & 16.46402 & 7.293057 & 4.808373 & 10.18736 & 12.15817 \\
\hline 9 & 3.450260 & 41.41439 & 5.537090 & 16.62544 & 7.591878 & 5.263860 & 10.99534 & 12.57201 \\
\hline 10 & 3.501625 & 40.47397 & 5.413336 & 16.18482 & 7.742942 & 5.659231 & 11.65476 & 12.87094 \\
\hline
\end{tabular}

Appendix 1b: Variance Decomposition of MSY:

\begin{tabular}{|c|c|c|c|c|c|c|c|c|}
\hline Period & S.E. & $\mathrm{RY}$ & MSY & BDY & DCY & PSY & INVY & RDR \\
\hline 1 & 2.436666 & 1.159344 & 98.84066 & 0.000000 & 0.000000 & 0.000000 & 0.000000 & 0.000000 \\
\hline 2 & 3.328561 & 0.823507 & 71.75056 & 23.50882 & 3.350481 & 0.036330 & 0.176662 & 0.353634 \\
\hline 3 & 4.389848 & 2.193690 & 52.07115 & 31.90561 & 10.96061 & 0.228024 & 0.128934 & 2.511979 \\
\hline 4 & 5.365482 & 3.081203 & 37.67357 & 37.73093 & 17.39743 & 0.164838 & 0.109383 & 3.842653 \\
\hline 5 & 5.933644 & 2.550422 & 31.40185 & 37.37318 & 21.40626 & 0.903728 & 0.267878 & 6.096680 \\
\hline 6 & 6.354814 & 2.293476 & 27.54303 & 35.45559 & 22.53199 & 2.585768 & 1.124349 & 8.465801 \\
\hline 7 & 6.738826 & 2.472239 & 24.52580 & 33.70080 & 22.47304 & 4.109298 & 2.707242 & 10.01157 \\
\hline 8 & 7.094996 & 2.688462 & 22.15451 & 32.48110 & 21.87258 & 4.903035 & 4.694321 & 11.20599 \\
\hline 9 & 7.411980 & 2.798147 & 20.30429 & 31.73474 & 21.30501 & 5.341417 & 6.532935 & 11.98345 \\
\hline 10 & 7.660620 & 2.921686 & 19.01954 & 30.79224 & 20.90325 & 5.744788 & 8.037293 & 12.58119 \\
\hline
\end{tabular}

Appendix 1c: Variance Decomposition of BDY:

\begin{tabular}{|c|c|c|c|c|c|c|c|c|}
\hline Period & S.E. & RY & MSY & BDY & DCY & PSY & INVY & RDR \\
\hline 1 & 5.417552 & 51.81754 & 0.949010 & 47.23346 & 0.000000 & 0.000000 & 0.000000 & 0.000000 \\
\hline 2 & 8.655219 & 31.83313 & 1.630625 & 62.09282 & 2.699099 & 0.149994 & 0.003484 & 1.590851 \\
\hline 3 & 10.90826 & 24.89655 & 2.808388 & 60.43531 & 7.185633 & 0.096121 & 0.084740 & 4.493262 \\
\hline 4 & 12.01601 & 22.21928 & 2.762101 & 58.69061 & 10.53737 & 0.080080 & 0.076083 & 5.634480 \\
\hline 5 & 12.43682 & 21.35207 & 2.595853 & 56.61901 & 12.09116 & 0.264238 & 0.540159 & 6.537509 \\
\hline 6 & 12.70189 & 20.62666 & 2.672451 & 54.56685 & 12.69496 & 0.882014 & 1.418393 & 7.138678 \\
\hline 7 & 12.93077 & 19.92048 & 2.859826 & 52.76943 & 13.09981 & 1.536444 & 2.282689 & 7.531310 \\
\hline 8 & 13.13792 & 19.30003 & 2.955243 & 51.38552 & 13.48124 & 1.943505 & 3.048924 & 7.885541 \\
\hline 9 & 13.35312 & 18.68354 & 2.974409 & 50.31754 & 13.83031 & 2.237770 & 3.739846 & 8.216583 \\
\hline 10 & 13.57163 & 18.10100 & 2.977506 & 49.31495 & 14.06465 & 2.570338 & 4.369914 & 8.601647 \\
\hline
\end{tabular}

Appendix 1d: Variance Decomposition of DCY:

\begin{tabular}{|c|c|c|c|c|c|c|c|c|}
\hline Period & S.E. & RY & MSY & BDY & DCY & PSY & INVY & RDR \\
\hline 1 & 4.761496 & 2.438248 & 59.25219 & 1.605229 & 36.70433 & 0.000000 & 0.000000 & 0.000000 \\
\hline 2 & 6.772048 & 1.415145 & 61.68189 & 15.89543 & 19.68751 & 0.028600 & 1.151331 & 0.140092 \\
\hline 3 & 8.259840 & 3.542681 & 54.55569 & 21.29372 & 13.98936 & 2.901622 & 3.621466 & 0.095462 \\
\hline 4 & 9.474375 & 7.340875 & 47.94264 & 21.24313 & 12.89197 & 5.183147 & 5.278361 & 0.119889 \\
\hline 5 & 9.865191 & 7.944512 & 46.00054 & 20.24860 & 13.72221 & 5.726717 & 6.142533 & 0.214886 \\
\hline 6 & 9.982837 & 7.768793 & 45.25476 & 19.95720 & 14.36116 & 5.768055 & 6.680173 & 0.209864 \\
\hline 7 & 10.06390 & 7.974409 & 44.58317 & 19.80130 & 14.83908 & 5.677927 & 6.889663 & 0.234450 \\
\hline 8 & 10.13603 & 8.043490 & 44.07748 & 19.75991 & 15.31529 & 5.605687 & 6.809286 & 0.388854 \\
\hline 9 & 10.35057 & 7.796091 & 42.52009 & 21.33761 & 15.52410 & 5.375755 & 6.606879 & 0.839477 \\
\hline 10 & 10.67750 & 7.491359 & 40.11240 & 23.60699 & 15.58251 & 5.052239 & 6.463692 & 1.690806 \\
\hline
\end{tabular}

Appendix 1e: Variance Decomposition of PSY:

\begin{tabular}{|c|c|c|c|c|c|c|c|c|}
\hline Period & S.E. & RY & MSY & BDY & DCY & PSY & INVY & RDR \\
\hline 1 & 2.028443 & 0.018648 & 62.20938 & 29.35901 & 0.906600 & 7.506367 & 0.000000 & 0.000000 \\
\hline 2 & 3.018453 & 2.493621 & 37.27478 & 18.54925 & 5.162959 & 36.19384 & 0.027686 & 0.297866 \\
\hline 3 & 4.548392 & 4.983473 & 24.75573 & 8.418111 & 11.02117 & 48.63870 & 0.021709 & 2.161110 \\
\hline 4 & 5.759936 & 5.547871 & 18.37581 & 5.336073 & 13.86208 & 54.29085 & 0.506345 & 2.080965 \\
\hline 5 & 6.348350 & 7.764023 & 15.80351 & 4.967827 & 15.77322 & 52.47448 & 1.486398 & 1.730542 \\
\hline 6 & 6.674108 & 9.658167 & 14.31531 & 6.481668 & 16.69861 & 48.65142 & 2.495881 & 1.698940 \\
\hline 7 & 6.900618 & 10.53427 & 13.39693 & 7.632433 & 16.85913 & 45.59367 & 3.777501 & 2.206070 \\
\hline 8 & 7.072881 & 10.87642 & 12.75424 & 7.916747 & 16.72039 & 43.60620 & 5.452648 & 2.673366 \\
\hline 9 & 7.235807 & 11.04855 & 12.18732 & 7.931266 & 16.60106 & 42.38685 & 6.988661 & 2.856298 \\
\hline 10 & 7.383412 & 11.33924 & 11.72414 & 8.056915 & 16.61626 & 41.39407 & 7.982604 & 2.886771 \\
\hline
\end{tabular}


Appendix 1f: Variance Decomposition of INVY:

\begin{tabular}{|c|c|c|c|c|c|c|c|c|}
\hline Period & S.E. & $\mathrm{RY}$ & MSY & BDY & DCY & PSY & INVY & RDR \\
\hline 1 & 2.087245 & 7.412584 & 6.547616 & 0.280178 & 6.304266 & 1.307220 & 78.14814 & 0.000000 \\
\hline 2 & 2.800145 & 7.333562 & 6.986703 & 0.174682 & 6.476502 & 2.325763 & 76.22194 & 0.480843 \\
\hline 3 & 3.077350 & 6.895961 & 8.912807 & 1.399130 & 5.821915 & 4.785261 & 71.29405 & 0.890872 \\
\hline 4 & 3.282031 & 6.791718 & 10.95085 & 6.255864 & 5.327984 & 5.585454 & 64.28450 & 0.803627 \\
\hline 5 & 3.414637 & 6.755968 & 11.34390 & 10.34459 & 5.392425 & 5.224423 & 60.01215 & 0.926548 \\
\hline 6 & 3.471841 & 6.699103 & 11.35215 & 11.31635 & 5.724827 & 5.093362 & 58.45506 & 1.359145 \\
\hline 7 & 3.488211 & 6.638301 & 11.43696 & 11.40354 & 5.906297 & 5.065024 & 58.00142 & 1.548446 \\
\hline 8 & 3.495085 & 6.639719 & 11.59261 & 11.42047 & 5.937150 & 5.047656 & 57.78222 & 1.580179 \\
\hline 9 & 3.501634 & 6.627648 & 11.69840 & 11.47574 & 5.946521 & 5.033753 & 57.63011 & 1.587831 \\
\hline 10 & 3.505688 & 6.612793 & 11.70893 & 11.51645 & 6.004055 & 5.024209 & 57.52695 & 1.606617 \\
\hline
\end{tabular}

Appendix 1g: Variance Decomposition of RDR:

\begin{tabular}{|c|c|c|c|c|c|c|c|c|}
\hline Period & S.E. & RY & MSY & BDY & DCY & PSY & INVY & RDR \\
\hline 1 & 2.045219 & 1.144458 & 5.244585 & 0.007195 & 2.899231 & 0.026948 & 6.982666 & 83.69492 \\
\hline 2 & 2.977575 & 12.80744 & 2.897142 & 7.717417 & 6.566641 & 10.94528 & 9.157484 & 49.90859 \\
\hline 3 & 3.797559 & 19.80813 & 1.781721 & 4.911568 & 4.510193 & 16.81157 & 11.26862 & 40.90820 \\
\hline 4 & 4.046872 & 19.79057 & 1.570162 & 4.335327 & 4.407131 & 17.42199 & 12.58966 & 39.88517 \\
\hline 5 & 4.165836 & 20.54148 & 1.509788 & 4.258609 & 4.710671 & 16.46408 & 14.30628 & 38.20909 \\
\hline 6 & 4.228225 & 20.34434 & 1.482744 & 4.141644 & 4.709224 & 16.00165 & 15.97868 & 37.34172 \\
\hline 7 & 4.275068 & 20.08823 & 1.991172 & 4.303032 & 4.710446 & 15.84232 & 16.48840 & 36.57640 \\
\hline 8 & 4.360568 & 19.56458 & 2.888697 & 6.003188 & 4.537822 & 15.74297 & 16.07554 & 35.18720 \\
\hline 9 & 4.424134 & 19.21607 & 3.456113 & 7.438866 & 4.423395 & 15.56521 & 15.71599 & 34.18436 \\
\hline 10 & 4.444612 & 19.18766 & 3.652036 & 7.686384 & 4.423584 & 15.46039 & 15.70432 & 33.88563 \\
\hline
\end{tabular}

